\title{
Prophet among Rebels: Henry David Thoreau and the Creation of a Transcendentalist Bible
}

\author{
Lydia Willsky-Ciollo \\ Fairfield University, Iciollo@fairfield.edu
}

Follow this and additional works at: https://digitalcommons.fairfield.edu/religiousstudies-facultypubs Copyright 2013 MIT Press

\section{Peer Reviewed}

\section{Repository Citation}

Willsky-Ciollo, Lydia, "Prophet among Rebels: Henry David Thoreau and the Creation of a Transcendentalist Bible" (2013). Religious Studies Faculty Publications. 105.

https://digitalcommons.fairfield.edu/religiousstudies-facultypubs/105

\section{Published Citation}

Willsky, Lydia. "Prophet among Rebels: Henry David Thoreau and the Creation of a Transcendentalist Bible." New England Quarterly 86, no. 4 (2013): 625-654 10.1162/TNEQ_a_00322

This item has been accepted for inclusion in DigitalCommons@Fairfield by an authorized administrator of DigitalCommons@Fairfield. It is brought to you by DigitalCommons@Fairfield with permission from the rightsholder(s) and is protected by copyright and/or related rights. You are free to use this item in any way that is permitted by the copyright and related rights legislation that applies to your use. For other uses, you need to obtain permission from the rights-holder(s) directly, unless additional rights are indicated by a Creative Commons license in the record and/or on the work itself. For more information, please contact digitalcommons@fairfield.edu. 


\title{
Prophet among Rebels: Henry David Thoreau and the Creation of a Transcendentalist Bible
}

\author{
LYDIA WILLSKY
}

How happens it that we reverence the stones which fall from another planet, and not the stones which belong to this-another globe, not this-heaven, and not earth? Are not the stones in Hodge's wall as good as the aerolite at Mecca? Is not our broad backdoor stone as good as any corner-stone in heaven. It would imply the regeneration of mankind if they were to become elevated enough to truly worship sticks and stones.

\section{—Henry David Thoreau, Wild Fruits}

T $\mathrm{N}$ both historical and popular accounts, Henry David 1 Thoreau, the famed Concord divine, is often referred to as a "prophet." Many readers will readily agree that he assumed the critical and admonitory responsibilities of that role-most conspicuously in "Civil Disobedience" — as well its commitment to proselytization. Few have recognized, though, just how fully he embraced the most distinctive and decidedly controversial element of "prophethood." Like the biblical prophets before him, I will argue, Thoreau sought to produce scripture. ${ }^{2}$ Earlier works, such as Walden or A Week on the Concord and Merrimack

${ }^{1}$ The references to Thoreau as a prophet are myriad. See, e.g., Paul Lauter, "Thoreau's Prophetic Testimony," Massachusetts Review 4.1 (Autumn 1962): 111-23, and Robert Sullivan, The Thoreau You Don't Know: What the Prophet of Environmentalism Really Meant (New York: HarperCollins, 2009).

${ }^{2}$ There are numerous definitions of the term "scripture"; for the aims of this paper, I take "scripture" to refer to a text or series of texts that are deemed sacred and authoritative in conception (by the author) or reception (by a person or persons who reads or encounters them), common examples being the Bible and the Qu'ran. Wild

The New England Quarterly, vol. LXXXVI, no. 4 (December 2013). (C) 2013 by The New England Quarterly. All rights reserved. doi:10.1162/TNEQ_a_oo322. 
Rivers, are notably suffused with religious motifs and amply reveal Thoreau's devotional love of nature. Thoreau did not emerge in full prophetic guise, however, until he produced his final manuscript, Wild Fruits. ${ }^{3}$

Before I launch my investigation, the term "prophet" requires some clarification in the context of this essay. Following a definition established by Max Weber, I characterize Thoreau as an "exemplary prophet," as distinguished from an ethical prophet. The exemplary prophet is an individual who, "by his personal example, demonstrates to others the way to religious salvation," whereas an ethical prophet speaks directly for god and "demands obedience as an ethical duty." 4 As I will show, Thoreau composed Wild Fruits to stimulate similar acts of inspiration in others, which would ultimately lead to a salvific and liberating experience of the divine. Into Weber's understanding of the exemplary prophet, I incorporate the observations of James Darsey, whose comparison of radical reformers and Old Testament prophets concludes that both engage in prophetic speech that bears a clear "sense of mission, a desire to bring the practice of the people into accord with a sacred principle, and an uncompromising, often excoriating stance toward a reluctant audience." 5 Thoreau qualifies as both reformer and prophet according to Darsey's scheme, as evidenced in Wild Fruits. Building upon both Weber's and Darsey's models, then, I define the term "prophet" as it applies to Thoreau as an individual with a clear sense of sacred purpose and divine mission whose intention is to lead others in word and deed to do what he does by his own example, which, in this specific case, involved

Fruits is deemed "scripture" according to this definition because Thoreau hoped and believed the work could serve that purpose (thus it is scripture in conception). In similar fashion, I apply the term "gospel" to Wild Fruits. "Gospel," in this context, refers to a firsthand account, subsequently reported (or recorded), that details a person's particular encounter with the divine.

${ }^{3}$ Henry David Thoreau, Wild Fruits: Thoreau's Rediscovered Last Manuscript, ed. Bradley Dean (New York: W. W. Norton \& Company, 200o), p. 168.

${ }^{4}$ Max Weber, Economy and Society (Wirtschaft und Gesellschaft), ed. Guenther Roth and Claus Wittich (Berkeley: University of California Press, 1978), pp. 447-48.

5 James Darsey, The Prophetic Tradition and Radical Rhetoric in America (New York: New York University Press, 1997), p. 16. 
the creation of new scripture. Not until the last few years of his life did Thoreau felt secure enough in his writing and in his prophetic ability to consciously compose what would become his version of nature's bible. And with his bible, he set out to turn humanity's gaze from the skies, where the JudaeoChristian God was thought to dwell, to the earth and to nature. ${ }^{6}$

Wild Fruits, left unpublished at his death, was Thoreau's culminating act of prophesy, designed to return humans to their "primitive" selves, thus enabling them to experience an original relation to the divine. Even more crucial to the prophetic function of the text, however, was Thoreau's belief that it was scripture. In a journal entry dated 16 October 1859 in which he referred to a new discovery he had made during the course of his daily walk, he wrote, "There will be some reference to it by way of parable or otherwise, in my New Testament. Surely it is a defect in our Bible that it is not truly ours, but a Hebrew bible. The most pertinent illustrations for us are to be drawn, not from Egypt or Babylonia, but from New England."7 Henceforward, until his death in 1861, Thoreau was consumed by a desire to "write nature," specifically the nature of New England, and to produce out of it an alternative sacred text. ${ }^{8}$

As a transcendentalist living during an era in which the concept of an established biblical "canon" was being challenged, Thoreau undertook a scriptural project that was representative of his particular philosophy as well as of his historical and geographical location. In that period, new revelation was not uncommon, if not always widely accepted, as with Joseph Smith and the Latter Day Saints. Thoreau also found in transcendentalism a philosophical imperative to test his potential, to expand his view of the world, and to become the divine prophet that all humans could become. Despite its seeming correspondence

\footnotetext{
${ }^{6}$ Throughout the text, I use the term "nature" to refer to the world outside and "Nature" to mean the powerful and creative entity that has an agency of its own and can enact change in the world. These terms echo what I believe to be Thoreau's own distinctions between nature, the earthly reality, and Nature, the divine force.

${ }^{7}$ The Journal of Henry David Thoreau, ed. Bradford Torrey and Francis H. Allen, 14 vols. (Salt Lake City: Gibbs M. Smith, Inc., 1984), 12:389.

${ }^{8}$ Sharon Cameron, Writing Nature: Henry Thoreau's "Journal" (New York: Oxford University Press, 1985).
} 
to the culture of its moment, however, Wild Fruits was unlike any other transcendentalist or alternative scriptural project. Thoreau's "new testament" reads at times like a botany textbook, at times like a landscape painting, and at others like the meditations of a pious ascetic who perceived God to be tactilely present in the world. Thoreau created scripture that was, for lack of a better term, thoroughly Thoreauvian, a text that encompassed both his naturalistic and his poetic proclivities. The determination to write Wild Fruits, as well as his style of writing it and plans for its publication, all reflect Thoreau's desire to make nature biblical. Further, if he were to be nature's rightful prophet, precedent demanded that he broadcast her revelation. Wild Fruits was Thoreau's gospel.

\section{The Nineteenth Century and the Open Canon}

During the nineteenth century, American Protestants danced very near to what historian David Holland has called the "canonical border."9 In the fourth century, the church closed its biblical borders when it ordained the canon complete and unalterable. Thereby, it effectively silenced (or, at least, intended to silence) would-be prophets as it deemed all subsequent pronouncements and mandates extrabiblical and, therefore, nonbinding. Of course, the proclamation did not thwart competing understandings of canonicity. Disputes over which books should be retained and which removed from the canon were present from its creation and have persisted ever since. ${ }^{10}$ Puritans who left England for America carried with them a firm belief in the

${ }^{9}$ David F. Holland, Sacred Borders: Continuing Revelation and Canonical Restraints in Early America (New York: Oxford University Press, 2011). Holland defines the Christian canon as those texts accepted by a particular church body as authoritative and binding. Throughout American history, but during the nineteenth century in particular, he argues, this border became increasingly blurred as more people tested the boundaries of the canon by critiquing or questioning established canonical texts, offering unorthodox interpretations of said texts, or in the most extreme cases, composing or "receiving" new sacred texts as additions to the established canon.

${ }^{10}$ Although the canon was effectively "set" in the fourth century, councils continued to debate it through the eighth. In the eleventh century, when the Eastern Orthodox Church and the Roman Catholic Church split, the two bodies disagreed about the canonicity of certain books, now referred to as the Apocrypha. Later, Protestants scrutinized certain books, especially James and Revelation. 
providence of God, which theoretically allowed for additions to the canon as God revealed himself more fully to man. ${ }^{11}$ And so, since the canon would need to be tested against any "new knowledge" emanating from God, the text became inherently vulnerable. ${ }^{12}$ Thus, even though they were stalwart defenders of a closed canon, the Puritans paradoxically provided ample precedent for many of the nineteenth century's canonical transgressions.

Additional factors contributed to the boom of new interpretations and new sacred texts in the nineteenth century. Arguably, the most definitive was disestablishment. In the words of Ann Douglas, disestablishment "typified and accelerated a historical process with complex roots in the general democratization and industrialization of American culture," of which the result was "an apparent triumph for the competitive, commercial, and individualistic spirit."13 The constitutional rejection of the concept of a state church created a singularity in American religion. With no one church mandated to set rules and to govern, every religious group held equal clout. As churches, sects, and denominations multiplied, so did opinions about the biblical canon. Since no sole body could regulate these proliferating interpretations, the canonical border began to buckle under their onslaught.

Biblical higher criticism, which rose to prominence in the late nineteenth century, also challenged the canon, for it fundamentally changed the course of biblical interpretation. ${ }^{14}$ As

\footnotetext{
${ }^{11}$ I use the term "providence" to denote God's plan for the world, in which humanity plays a role, as does the natural world.

${ }^{12}$ Critical of the Catholic Church for the mere inclusion of the Apocrypha in the Bible and the Anglican Church for its creation of "extrabiblical" material, specifically the Book of Common Prayer, the Puritans vehemently opposed any addition to the biblical canon. See Holland, Sacred Borders, p. 17; also chap. 2.

${ }^{13}$ Ann Douglas, The Feminization of American Culture (New York: Knopf, 1977), pp. 23-24.

${ }^{14}$ Jerry Wayne Brown contends that historians have misdated the advent of higher criticism in America and that, in fact, certain religious figures were already employing or critiquing the higher critical methods long before it exploded onto the scene in the latter part of the nineteenth century. See his The Rise of Biblical Criticism in America, 1800-1870: The New England Scholars (Middletown, Conn.: Wesleyan University Press, 1969).
} 
Hans Frei explains, the Bible was being "subjected to independent investigation to test [its] veracity" and to penetrate "the thoughts of the biblical authors and the origin and shape of the writings on the basis of the most likely, natural, and specific conditions of history, culture and individual life out of which they arose."15 Every biblical doctrine, claim, or story found not to be historically accurate was deemed spurious, thus destabilizing the authority not only of the Bible but of Christianity. Outside of Roman Catholicism, no religious body had the incontrovertible authority to deem an alternative scripture heretical. Texts that had originally been dismissed as secular were reemerging as viable options to the books of the Christian Bible. Scripture from Asia, from India in particular, had begun making inroads in America, especially within the nineteenth century "seeker" culture, of which the transcendentalists were a part. ${ }^{16}$ Moreover, some were not simply content to treat the open canon as a license to read formerly noncanonical texts as scripture. Lawrence Buell has tracked how what he terms "the erosion of the Bible's privileged status" inspired poets and "creative writers" to explore the possibility that literature could serve "as a legitimate and even rival means of conveying spiritual experience." ${ }^{17}$ In sum, cultural and intellectual forces had flung open the doors of the closed canon, welcoming aspiring prophets and evangelists to contribute a line of scripture. Few seriously considered taking on such a task. Of those few who did, an inordinate percentage hailed, perhaps unsurprisingly, from Christian sects and new religious movements. ${ }^{18}$

${ }^{15}$ Hans Frei, The Eclipse of the Biblical Narrative: A Study of Eighteenth- and Nineteenth-Century Hermeneutics (New Haven: Yale University Press, 1974), p. 18.

${ }^{16}$ Leigh Schmidt, Restless Souls: The Making of American Spirituality (New York: HarperCollins, 2005).

${ }^{17}$ Lawrence Buell, New England Literary Culture: From Revolution through Renaissance (Cambridge: Cambridge University Press, 1986), p. 167.

${ }^{18}$ The most well-known examples of new scripture in the nineteenth century are Joseph Smith's Book of Mormon (1830) and Book of Moses (1851) (see Richard Bushman, Joseph Smith, Rough Stone Rolling: A Cultural Biography of Mormonism's Founder [New York: Vintage Books, 2005], and Jan Shipps, Mormonism: The Story of a New Religious Tradition [Urbana: University of Illinois Press, 1985]), and the printing of the "Shaker's Bible," Holy, Sacred and Divine Roll and Book; from the Lord 
Despite their audacious charge across the canonical border, most who did endeavor to write a competing text did so out of a love for scripture, if not its historically sanctioned form. The Bible was being challenged, but America was still a bibliocentric nation: authoritative, sacred texts were still needed to guide belief and right living. Although the transcendentalists, including Thoreau, have been reproached as antibiblicists, they were, in fact, deeply invested in the culture of nineteenth-century scripturalism.

\section{Transcendentalism and the Extension of Prophetic Ability}

In 1854, transcendentalist writer Thomas Wentworth Higginson composed a tract entitled Scripture Idolatry in which he sought to expose "Protestant dependence on the Bible" and to "dismantle the Bible as a foundation of authority." 19 Higginson, like a number of transcendentalists, believed that an "idolatrous" reverence for the Bible, or any single sacred text, for that matter, ${ }^{20}$ stymied genuine religious experience. Theodore Parker, in his infamous sermon "The Transient and the Permanent in Christianity," criticized all reliance on the Bible and its doctrinal offshoots. "Men have been told that all these things must be taken as part of Christianity," he wrote, "and if they accepted the religion, they must take all these accessories along with it; that the living spirit could not be had without the killing letter." By the "killing letter" of the Bible, Parker meant that "authority [had been] taken for truth and not truth for

God of Heaven, to the Inhabitants of Earth (1843) (see Amy Stechler, The Shakers: Hands to Work, Hearts to God: The History and Visions of the United Society of Believers in Christ's Second Appearing from 1774 to the Present [New York: Aperture Foundation, 1987]). For a general overview of new scriptures of this period, see American Scriptures: An Anthology of Sacred Writings, ed. Lauri Maffly-Kipp (New York: Penguin Books, 2010), or Holland, Sacred Borders.

${ }^{19}$ Schmidt, Restless Souls, p. 110.

${ }^{20}$ Many transcendentalists, including Thoreau (see below), read extensively in other scriptural canons, particularly those of Eastern religions, among which Hindu texts such as the Vedas and the Bhaghavad Gita were paramount. 
authority." ${ }^{21}$ The Bible, with its hegemonic grip on truth, allowed little room for humanity to search for alternative sources or to receive and write out new truths.

In the transcendentalist worldview, scripture's fundamental problem was its tendency to become monolithic. At its best, scripture was an expression of the divine as experienced by the author who inscribed it. Yet the Bible, which the religious establishment treated as the only valid representation of such an encounter rather than as an example of God's interaction with certain historical persons, effectively precluded the possibility of further revelation and prophecy. Ralph Waldo Emerson, for one, objected. Humans, he insisted, had never lost the ability to receive revelation; rather, they had simply lost the wherewithal to test their prophetic abilities, which had withered away in the face of the longstanding claim that the Bible embodied all the truth they would ever require. In his "Harvard Divinity School Address" of 1838 , Emerson called for a "new Teacher" and a "new revelation" that would supplant and surpass all earlier forms of scripture. ${ }^{22}$ Emerson believed that this new teacher would be a poet, and the new revelation would be in the form of poetry. No one poet, however, could ever hope to provide a comprehensive account of all new revelation. As Emerson understood it, according to Buell, "poetry was written before time was, and when [people] try to record it, all [they] set down is fragments." ${ }^{3}$ Since God could not be contained, neither could the whole of poetry ever be recorded. Thus, its writing would be perpetual, because experiencing the divine was an ongoing process that would never cease nor result in the production of any text that could be exhaustive. The biblical canon's closed borders, then, were the true obstructions to belief, for they

\footnotetext{
${ }^{21}$ Theodore Parker, "The Transient and Permanent in Christianity," sermon presented at the ordination of Rev. Charles C. Shackford, Boston, Massachusetts, May 19, 1841, Andover-Harvard Library, Harvard University, bMS 101.

${ }^{22}$ Ralph Waldo Emerson, "The Harvard Divinity School Address," in The Spiritual Emerson: Essential Writings, ed. David M. Robinson (Boston: Beacon Press, 2003), pp. 82 and 73 .

${ }^{23}$ Buell, New England Literary Culture, p. 129.
} 
made it impossible for new contributions to replace defunct ones. In the words of Emerson, "As long as the heart \& mind are illumined by a spiritual life there is no dead letter but a perpetual scripture." 24

Emerson's, like Parker's, involvement in the open canon culture of the nineteenth century was primarily critical and rhetorical. Holland maintains that Emerson was content to "[announce] the approach of new revelations"; he himself "did not necessarily have them." ${ }^{25}$ Thoreau, on the other hand, did, and he intended to write them down and share them with the world.

\section{Thoreau's Path to Prophethood}

Of all the people who had either a direct or indirect role in the creation of Wild Fruits, Emerson was most influentialfirst as Thoreau's mentor and later as his foil. Though Thoreau would ultimately break with Emerson in style, agenda, and even belief, Emerson had introduced him to many of the sources of inspiration that proved seminal for his work on Wild Fruits. The Vedas, for example, the oldest scripture of Hinduism, would become as instrumental for him as the Bible. He once wrote Emerson asking, "Is it not singular that while the religious world is gradually picking to pieces its old testaments, here are some coming slowly after on the sea-shore picking up the durable relics of perhaps older books, and putting them together again?"26 Thoreau was particularly drawn to Hinduism's theology of sight or seeing. From texts like the Laws of Manu and the Vedas, he gleaned that as an individual lived in the world, his or her sight became progressively clouded. Only if she or he meditated intensely on the self-or, more particularly,

\footnotetext{
${ }^{24}$ Ralph Waldo Emerson, The Journals and Miscellaneous Notebooks of Ralph Waldo Emerson, vol. 4, 1832-1834, ed. William H. Gilman et al. (Cambridge: Harvard University Press, 1964), p. 94.

${ }^{25}$ Holland, Sacred Borders, p. 173.

${ }^{26}$ Henry David Thoreau to Ralph Waldo Emerson, 17 October 1843, The Correspondence of Henry D. Thoreau, vol. 1: 1834-1848, ed. Robert N. Hudspeth (Princeton: Princeton University Press, 2013), p. 245
} 
on the self as reflected in nature-would sight be restored. "For transcendentalists," Alan Hodder observes, "nature supplanted scripture as the medium of divine revelation: nature as a whole, or in one of its parts, was the veritable mirror of the divine." 27

In the Vedas, Thoreau discovered a means of facilitating an engagement with nature; the prophetic language by means of which he recorded it, he adopted from the Christian Bible. Although his use of Christian language and symbols may have been less an active choice than a passive response to the culture that surrounded him, occasionally Thoreau's attachment to the Bible seems to extend beyond mere "residual impulses." He once declared in a letter to Isaiah Williams, for example, "If any soul look abroad even today it will not find any word which does it more justice than the New Testament." ${ }^{28}$ Still, despite such lofty pronouncements, the Bible apparently left him unfulfilled, as, in turn, would the Vedas. Nature alone held the key to the truth, and to date, no one had successfully written nature's Bible. Eventually, Thoreau realized, that task had been reserved for him. His path to prophethood was characterized by this gradual shift in self-understanding, a shift from reader to writer of scripture.

Yet, how was he to compose such a text? Here, Thoreau bore another debt to Emerson. Beyond introducing Thoreau to Indic scripture, Emerson offered him a philosophy (transcendentalism) and a writing style (poetry). For a time, Thoreau's philosophy mimicked Emerson's. Transcendentalism, at its genesis, was highly Platonic. Deriving from that system of thought the notion that the human mind has remained essentially unchanged throughout time, Emerson argued that poetry, which is eternal and evocative of the divine in humanity, always represents human experience more accurately than does history. ${ }^{29}$ Given that conviction, Emerson repeatedly encouraged

${ }^{27}$ Alan D. Hodder, "Ex Oriente Lux': Thoreau's Ecstasies and the Hindu Texts," Harvard Theological Review 86.4 (October 1993): 422.

${ }^{28}$ Thoreau to Isaiah Thornton Williams, 8 September 1841, Correspondence, p. 89.

${ }^{29}$ Ralph Waldo Emerson, "Nature," in The Spiritual Emerson, p. $5^{8 .}$ 
Thoreau to contribute poetry to The Dial, and he expressed his disappointment when Thoreau turned increasingly to prose. ${ }^{30}$

More than likely, Thoreau's refusal to write in the style most agreeable to Emerson was the primary reason for the rift in the men's friendship. The divergence in their theological views was far subtler. Nature had always been a common source of inspiration and delight for the two friends. As was the pattern in their relationship, Thoreau at first shared Emerson's Platonic understanding that nature and the Soul were distinct. For Emerson, nature was a spiritual means to a highly personal end: when an individual meditated on nature, he accessed his own soul. In other words, Emerson revered Nature as a creative force but believed it was ultimately subsumed by the power of the Soul. Thoreau, on the other hand, did not overlook nature's materiality. For Thoreau, the members of a "sort of transcendentalist trinity" - namely "God, humanity, and nature"-were discrete entities with their own characteristics, abilities, and power even though each was intimately bound to the other two. ${ }^{3^{1}}$ Nature, in this sense, was not simply serviceable as an entrée to God but valuable in its own right as both a force and a thing that affected humanity's lived experience. Nature, in short, had both divine power and materiality.

During the course of human history, however, nature, the thing, had become divorced from Nature, the force. Most often, humans appreciated nature only for its aesthetic merits at best and its commercial advantages at worst, giving little thought to its divine powers. Humans had become alienated from nature and thus had lost, as Paul David Johnson has remarked, their "primary instinctual relationship to the land."32

$3^{\circ}$ Robert Richardson, Henry Thoreau: A Life of the Mind (Berkeley: University of California Press, 1986), pp. 266, 270-71. The Dial was the short-lived transcendentalist periodical run by Margaret Fuller with a guiding hand from Emerson. It was conceived as a vehicle for transcendentalist thoughts and ideas.

${ }^{31}$ Richardson, Thoreau: A Life of the Mind, p. 7.

${ }^{32}$ Paul David Johnson, "Thoreau's Redemptive Work," American Literature 49.1 (March 1977): 27. Thoreau's views on capitalism and the commodification of the natural world first appeared in print in Walden, its chapter on "Economy" being the most well-known example of this critique. Thoreau carried this view through to Wild Fruits. 
Thoreau's holistic view of nature, and thus his departure from Emersonian thought, is evident in Wild Fruits, where nature appears as both Creator and creation. While the Bible and the Vedas offer details of life on earth, in Thoreau's telling, such particulars consist of intricate descriptions of natural phenomena. As in the established sacred texts with which he was familiar, Thoreau evoked the supremacy of the Creator, filling the pages of Wild Fruits with prayers of thanksgiving and an awestricken love of Nature. When he followed a path to the Soul through nature, Emerson expected to leave scripture behind; Thoreau intended to develop scripture out of nature and to offer it back to the world.

\section{Exploring Scriptural Themes in "Walden" and Other Early Writings}

By the time Walden was published in 1854 , Thoreau's goals for writing had grown increasingly toward the scriptural and steadily away from Emerson's poetic ideal. Thoreau had long been dabbling with such ideas in his writing, but they would not come to fruition until he produced Wild Fruits. For example, the concept he developed therein that divine insight and inspiration were derived from sensory experience was a motif he first introduced in Walden. In the chapter "Sound," he asked, "Will you be a reader, a student merely, or a seer?"33 For Thoreau, "sight" had both physical and spiritual aspects. Throughout Walden and most of his later essays, as well as in Wild Fruits, he habitually registered and recorded in exquisite detail what he saw, touched, tasted, or heard, thereby creating a vivid image of his surroundings. Evolving out of that close observation, Thoreau believed, was a second or transcendent sight. "We are enabled to apprehend at all what is sublime and noble," he insisted, "only by the perpetual instilling and drenching of the reality that surrounds us."34

\footnotetext{
${ }^{33}$ The Writings of Henry David Thoreau: Walden, ed. J. Lyndon Shanley (Princeton: Princeton University Press, 2004), p. 111.

${ }^{34}$ Thoreau, Walden, p. 97.
} 
Thoreau often resorted to the metaphor of Walden Pond's reflective waters to demonstrate how the close observation of nature can yield surprising findings and new understandings. This notion that humanity knows itself best when immersed in nature was another thematic thread that Thoreau drew through many of his essays and into Wild Fruits. By reintroducing humans to the proper use of their senses, Thoreau hoped, they would develop a better understanding of themselves as spiritual creatures. Somewhere along the way, the woods had become foreign territory to them, and he was committed to restoring them to their primitive state in nature. Although Walden did not yet bear the prophetic or admonitory tone of Wild Fruits, it is clear that Thoreau was beginning to understand his mission.

In Walden and A Week on the Concord and Merrimack Rivers, Thoreau conceived of humanity's relation to nature as a palpable reality. While this self-conscious materiality by no means disappears, later works, namely his Maine excursion essays and Cape Cod, more directly confront the idea of Nature as a divine, creative force. Much of Thoreau's writing on nature focuses on its benevolent aspects, but in Ktaadn and Cape Cod, Cape Cod in particular, he depicts nature in much the same way as God is portrayed in parts of the Bible: as fearsome, just, and full of wrath. Cape Cod reports the devastating effects of one particular storm, in the wake of which the debris (including human remains) from a ship sunk off the coast washed up on shore. Writing about the aftereffects of the tragedy, Thoreau mused, "The stranger and the inhabitant view the shore with very different eyes. The former may have come to see and admire the ocean in a storm; but the latter looks on it as the scene where his nearest relatives were wrecked." 35 Though he assumed a scientist's objectivity in his description, Thoreau remarked in his journal that he felt at once delighted and perturbed by nature's ability to be simultaneously wonderful and grotesque..$^{6}$ That ambivalence toward nature, which is

${ }^{36}$ Thoreau, Journal, 4:107. 
never resolved in Cape Cod, persists in Wild Fruits. Whereas Walden and A Week are designed to model how to live in, observe, and experience nature, the later essays mirror the rapt adoration and corresponding fear of a man who has seen God in the hills and beaches of New England.

As others had done and would do, Thoreau could have traveled elsewhere- the Alps, the Amazon— to discover landscapes that would more dramatically embody nature's power. Instead, he deliberately created a local vision of the sacred. Ultimately, Wild Fruits would have a proper setting (New England), a set of rules for living (his modeling of proper observation and engagement of the senses), an underlying, ultimately salvific aim (to return humanity to its primitive relation to nature), as well as a devotional and pious tone. Viewing his earlier works through Wild Fruits, it is easy to see them as experiments, attempts to discover his prophetic voice and forays into the many ideas that would later shape his grand scriptural project. Although Thoreau referred to Wild Fruits alone as scripture, Walden, A Week, his Maine essays, and Cape Cod were certainly part of a developing biblical narrative; they may not have been canonical, but they were decidedly inspired.

\section{"Wild Fruits," Nature's Bible}

To Thoreau, the very idea of a scriptural canon was absurd. It was simply illogical to think that scripture-in its grandest sense-could ever express Nature (read: God) in its totality. Nouns and adjectives were woefully insufficient to the daunting task of depicting omniscient, eternal Nature. ${ }^{37}$ Thoreau never aspired to exhaustively describe all of nature but, rather, to "record" it so that humanity might "establish a relation to it." 38 Creating an accurate record was not Thoreau's greatest concern in writing scripture. He was troubled that contemporary interpretative practices were at odds with his fundamental beliefs.

\footnotetext{
${ }^{37}$ Charles Feidelson Jr., Symbolism in American Literature (Chicago: University of Chicago Press, 1953), p. 137.

$3^{8}$ Cameron, Writing Nature, p. 148.
} 
At the time, biblical interpreters commonly assumed-an assumption derived from John Locke-that if one put aside one's personal prejudices and predilections, one could read the Bible clearly through the eyes of its authors. ${ }^{39}$ Thoreau rejected that notion outright. People could never strip themselves of their thoughts, ideas, their personhood; they were, by definition, historically conditioned.

Pushing the point, Thoreau insisted that no individual could ever see through another's eyes, whether that other were a prophet of yore or a close friend. Experience and understanding are always subjective. "Nature and human life are as various as our several constitutions," he wrote in Walden. "Who shall say what prospect life offers to another? Could a greater miracle take place than for us to look through each other's eyes for an instant? We should live in all the ages of the world in an hour; ay, in all the worlds of the ages. History, Poetry, Mythology! I know of no reading of another's experience so startling and informing as this would be." 40 Here was a paradox, and Thoreau confronted it head-on while composing Wild Fruits. The intention of his project was to bring nature to humanity through prose. In it, he enjoined humanity to experience nature through his eyes-an undertaking he knew to be impossible. He could never capture others' "original relation to the universe" in "Nature's Bible."41 And yet, he wrote it anyway.

Why? Despite the sheer absurdity of scripture making, Thoreau took his prophetic duties seriously. He understood that if he were to be the poet-seer-prophet of nature whom he idealized in his many works, he must find a way to bring people out-of-doors to do as he had done, to discover in nature their own scripture. The best tool at his disposal was his writing, and it was in this medium that he foresaw his best prospect for disseminating his message. His would be a new New Testament, a new Veda-new not simply by the date of

\footnotetext{
${ }^{39}$ Richard A. Grusin, Transcendentalist Hermeneutics: Institutional Authority and the Higher Criticism of the Bible (Durham, N.C.: Duke University Press, 1991), pp. $81-82$.

${ }^{40}$ Thoreau, Walden, p. 10.

${ }^{41}$ Emerson, "Nature," in The Spiritual Emerson, p. 23.
} 
its composition but because its subject matter would reflect the present, living world of New England. Whereas the Bible, Vedas, and other ancient scriptures spoke of a time long ago in a land far away, Thoreau recorded a revelation that he believed all might experience at any moment by means of their own senses.

Thoreau was an evangelist, but an evangelist quite different from Matthew, Mark, Luke, and John. Their mission was to tell the story of Jesus, convey his message, and corroborate its truth. Thoreau sought to impart his singular, personal truth so that, through his words, which would in turn prompt others to embark on their independent excursions, he might rouse them to look for their own, distinctive truth in nature. In Walden, as I have mentioned, Thoreau drew upon the pond as a metaphor for the poet-prophet. In his view, as Richard Schneider has explained, "[both] the seer and the pond were poets in their ability to capture the relationship between subject and object and between heaven and earth, and both could reveal the new and beautiful truth it contained. Like God, Nature and humanity were creators and revealers of truth. The poet's role was to help others to see that relationship so they could quit their lives of quiet desperation and become creative seers and reflectors of truth themselves." 42 In Wild Fruits, Thoreau set out to assume the aspect of the mirroring pond, to "reflect" nature's image for the benefit of his readers. They, in turn, would seek out nature themselves-he fervently hopedeventually becoming, themselves, poetic mirrors for nature's divinity. Thoreau's scriptural project was, thus, ongoing-and therefore potentially unhindered by the boundaries and unburdened by accretions associated with a "closed canon." Thoreau would create scripture to inspire more scripture, not to utter the final word on the subject.

Unfortunately, following Thoreau's abrupt death in 1862, his grand scriptural scheme came to a premature end, and so the countless scriptural projects he foresaw spiraling out from it p. 63 .

${ }^{42}$ Richard J. Schneider, Henry David Thoreau (Boston: Twayne Publishers, 1987), 
were precluded. Schneider insists that any compositional endeavor involving Thoreau's meticulous collection of data never went beyond the "note-taking" stage. Nor is it possible, he avers, to know "beyond a doubt whether the collection of such data was simply an elaborate means of artistic procrastination, whether he genuinely hoped to transform all his information into the symbolic truths of a larger work, or whether the collection of the material had value to him in its own right."43 Schneider is right, of course. Thoreau's death rendered moot any plans he had for the project, and he had not communicated his intentions in any formal sense to his friends and colleagues. ${ }^{44}$ However, enough evidence can be gleaned from his journal and from the manuscript of Wild Fruits to confirm that Thoreau had moved past note taking, even past conception, to execute a broad-scale, sacred project on nature.

The actual construction of Wild Fruits did not begin in earnest until 1859. On 25 February of that year, he lamented in his journal, "All the criticism which I got on my lecture on Autumnal Tints at Worcester on the $22 \mathrm{~d}$ was that I assumed that my audience had not seen so much of them as they had. But after reading it I am more than ever convinced that they have not seen much of them-that there are very few persons who do see much of nature."45 "Autumnal Tints" is, essentially, a love letter to the month of October. Long captivated by New England's fall colors, Thoreau describes them as if painting a landscape. Yet, as indicated in his journal entry, the audience's response to his vivid imagery was lukewarm, even critical. People no longer saw nature, he feared. In part, they lacked observational techniques. One could not simply walk into nature and expect instantaneous fulfillment. No, argued Thoreau, "you surely will see, and much more, if you are

\footnotetext{
${ }^{43}$ Schneider, Henry David Thoreau, p. 20.

${ }^{44}$ In his eulogy, Emerson made reference to Thoreau's "broken task," which editor Bradley Dean believes was a reference to Wild Fruits. Thoreau notes an interaction with his friend Bent about his "Book" in a 2 August 186o entry in his Journal (14:9). Short of these two snippets, there is no further documented evidence that he planned to turn Wild Fruits into a book manuscript or had indicated to anyone that he wrote it as scripture.

45Thoreau, Journal, 11:457.
} 
prepared to see it-if you look for it. . . . Objects are concealed from our view, not so much because they are out the course of our visual ray, as because we do not bring our minds to bear on them." 46 And so, in the midst of his dismay over how his lecture had been received, Thoreau discovered his mission: he must provide people with the descriptions, the images necessary to see nature in all the fullness of its glory. Six months later, he launched the project he referred to as "Wild Fruits." 47

Though begun in earnest in 1859, the foundation for Wild Fruits was laid in 1851. In 1837, at Emerson's suggestion, Thoreau started a journal. Its early volumes, when the younger man was still very much under the elder's wing, can be characterized as a "testing ground for transcendental thoughts." 48 Gradually, however, the journal became increasingly preoccupied with a scientific observation of the outside world, a shift particularly noticeable during his stay at Walden, and its pages came to catalog and record natural phenomena in intimate detail. On a separate set of loose sheets, Thoreau began composing notes for the unfinished manuscript that would be published almost a century and a half after his death as Wild Fruits. Into this separate document, Thoreau often transcribed passages directly from his journal; at other times, he left marginal notes for himself to do so at some future date. Moreover, for some time he had been recording field observations in several additional notebooks, two of which he called his "Common-Books." In separate volumes, he was also noting his thoughts on Native

\footnotetext{
${ }^{46}$ Henry David Thoreau, October, or Autumnal Tints (New York: W. W. Norton, 2012), p. 110.

${ }^{47} \mathrm{~A}$ statement about the provenance and publication of the manuscript is in order: Wild Fruits was published for the first time in 2000 by the Thoreau Society. It was edited from Thoreau's original manuscript, which was classified under the heading "Notes on Fruits" ("Wild Fruits" was Thoreau's original title), in the Henry W. and Albert A. Berg Collection of English and American Literature, New York Public Library, New York City. Dean notes that Thoreau had originally wrapped the manuscript in heavy paper, but when it was found, the pages had fallen out of place. Dean rearranged them in what he believes to be a close approximation of the original order. In addition, he included in full passages from Thoreau's journal that Thoreau had cited in the margins of his manuscript but had not yet transcribed into "Wild Fruits." See Wild Fruits, pp. 285-86.

${ }^{48}$ Schneider, Henry David Thoreau, p. 20.
} 
American history and recording excerpts from his reading on natural philosophy. All of these distinct endeavors he referenced or excerpted in his ballooning manuscript, which, by the time of his death, had grown to almost nine thousand pages. 49

Thoreau had accumulated an overwhelming amount of material. By 1859, he began to see the manuscript on "Wild Fruits" as something more than his personal encyclopedia of nature, although precisely what he had yet to determine. His attitude toward his journal was changing as well; it was no longer simply a compilation of natural data but, rather, a vehicle for sacred experience. "If by watching a whole year on the city's walls I may obtain a communication from heaven," wrote Thoreau in a journal entry of 7 September, "shall I not do well to shut up shop and turn a watchman? To devote your life to the discovery of the divinity in Nature or to the eating of oysters: would they not be attended with very different results. . . . To watch for, describe, all the divine features which I detect in Nature. My profession is to be always on the alert to find God in natureto know his lurking places." $5^{\circ}$ Thoreau aimed to record God in nature - the physical facts of the outside world - and Nature as God-the divine force driving creation through its perpetual cycles. With this newfound understanding, his writing would henceforth assume divine, biblical ramifications.

\section{A Gospel of the Wild}

Wild Fruits would be a practical gospel. As his experience with "Autumnal Tints" had shown, humans had lost touch with nature and their natural selves. From the start, Thoreau desired that his Bible not only "say" something but actively do something to remedy this defect. Throughout his life, he had struggled with how best to exist in nature. Walden, as well as his accounts of trips to Maine and Cape Cod, testified to the seriousness of that endeavor. At its heart was Thoreau's concept

\footnotetext{
${ }^{49}$ Dean, intro. to Thoreau, Wild Fruits, p. x.

${ }^{5}$ Henry David Thoreau, The Journal: 1837-1861, ed. Damion Searls (New York: New York Review of Books, 2009), p. 34.
} 
of the "wild," "wildness," or "wilderness." As it had become progressively more civilized, humanity had lost its wildness; that is, it had become cut off from nature, and each individual had become alienated from his or her own inner wild nature. That "wildness" in human nature was predicated upon an intrinsic, spiritual bond with nature, with God. Awakening to one’s own inner wild nature was the true "great awakening." Given his culture's reliance on sacred texts to establish rules and precedents for how to act and how to think, Thoreau certainly appreciated that if he were to prompt an awakening, he needed to produce a "newer testament," a "gospel according to the moment." ${ }^{1}$

Toward that end, Thoreau sought inspiration among the greatest living examples of human "wildness" in his proximity: Native Americans. His youthful fascination for "Indians" only gathered force as he grew older..$^{2}$ The separate notebook he kept to record information on Native Americans he referred to as his "Ante-Columbian History." 53 Joe Polis, his Indian guide during a trip to Chesuncook Lake (Maine), left a deep impression on him. ${ }^{54}$ In the 185 os, Thoreau began to comment explicitly on Native Americans' special affinity for the wild. If civilized whites could imitate Native Americans' wildness and, thus, recover their own, they might experience the awakening that Thoreau craved for them.

Given his quest to recapture the wild in humanity, Thoreau might be called a primitivist. He was not so in the vein of the New England Puritans, with whom the term is most often associated. 55 While the past-facing Puritans sought to re-create society based on a biblical model, Thoreau hoped to reinstate

${ }^{51}$ Thoreau, Journal of Thoreau, 2:428.

${ }^{52}$ Thoreau was reportedly notorious for his uncanny ability to find Native American artifacts by simply divining their presence. See his Journal, 12:90.

${ }^{53}$ Though he never published the volume, it certainly contained the requisite amount of material.

${ }^{54}$ Schneider notes that Thoreau admired Polis for his ability to "accept the virtues of civilization, reject its vices, and still maintain his Indian identity" (Henry David Thoreau, p. 83).

55Puritan "primitivism" reflected a desire to model society after apostolic times and to use the Bible as the only word and rule of faith. For more on primitivism among Puritans, see Theodore Dwight Bozeman, To Live Ancient Lives: The Primitivist Dimension in Puritanism (Chapel Hill: University of North Carolina Press, 1988); Perry 
people's original relationship to nature so that they might live more authentically in the present. While their inner nature would thus be reordered, their way of life and their civilization would not..$^{6}$ In such a fashion, Thoreau hoped to strip the words "wild" and "primitive" of their savage connotations and reinvest them with their life-giving, spiritual qualities.

Wild Fruits is saturated with this sacred desire to correct humanity's misunderstanding of wildness. In some instances, Thoreau addresses the issue quite literally. "Both Indians and whites," he writes, "ancients and moderns, have turned aside to pluck [raspberries]. Raspberries, as appear from recent stories, made part of the food of that unknown primitive people whose traces have been found in piles at the bottom of the Swiss lakes, probably before the foundation of Rome." 57 Humanity was connected to the past not through the history of raspberries but through raspberries themselves. Sense experience-in this particular case, the sight and taste of raspberries-is transcendent; to taste a raspberry is to be transported spiritually through all time and all human experience.

On other occasions, Thoreau's primitivist plea savored of a lament or jeremiad, and his tone turned equal parts wistful, laconic, and admonitory. In one such instance, he wrote, "I seem to have wandered into a land of greater fertility, some up-country Eden. These are the Delectable Hills. It is a land flowing with milk and huckleberries, only they have not yet put the berries into the milk. There the herbage never withers, there are abundant dews. I ask myself, What are the virtues of

Miller, "The Marrow of Puritan Divinity," in Errand into the Wilderness (Cambridge: Belknap Press of Harvard University Press, 1956); and Edmund S. Morgan, Visible Saints: The History of a Puritan Idea (Ithaca: Cornell University Press, 1963).

${ }^{56}$ This is, in a nutshell, Thoreau's experiment at Walden. Though his hut was built in the woods circling Walden Pond, he entertained visitors often and was not far from the center of Concord. Thoreau went to the woods to see if he could live primitively, in tune with his wild nature, while still being in civilization. Commenting on Thoreau's time at Walden, Richardson argues that "Thoreau's venture was in no sense a retreat or a withdrawal. He himself thought of it as a step forward, a liberation, a new beginning, or as he put it in the second chapter of Walden, an awakening to what is real and important in life" (Thoreau: Life of the Mind, p. 153).

${ }^{57}$ Thoreau, Wild Fruits, p. 27. Subsequent page citations to Wild Fruits will appear in the text. 
the inhabitants that they are thus blessed?" (p. 54). The allusion to Eden and Israel (the land of milk and honey) was pointed. Just as Adam and Eve had fallen from Eden, so had people fallen away from nature and from their primitive selves; and just as the chosen people had wandered many years in search of the Promised Land, so New Englanders of the nineteenth century were wandering about, exiled from nature.

Further, he asked, invoking Jeremiah, why should humanity be blessed with nature's gifts? Humans do little to deserve its bounties. Instead, they view nature only as a commodity to be sold or a plot to be claimed, not as the sacred source of divinity. "As long as the berries are free to all comers, they are beautiful, though they may be few and small; but tell me that this is a blueberry swamp which somebody has hired, and I shall not want even to look at it." The concept of "owning" a piece of nature was repugnant to Thoreau, especially if the owner were oblivious to nature's largesse. "We so commit the berries to the wrong hands; that is, to the hands of those who cannot appreciate them. This is proved by the fact that if we do not pay them some money, these parties will at once cease to pick them. They have no other interest in berries but a pecuniary one. Such is the constitution of our society that we make a compromise and permit the berries to be degraded-to be enslaved, as it were" (pp. 58-59). Far from worshiping Nature, humanity had enslaved it. And, even more disturbing, people had tricked themselves into believing that they themselves were free. They had established numerous institutions and crafted various systems to safeguard that freedom when in fact those various stratagems had only served to chain them ever more firmly to a static and uninspired life. "The church, the state, the school, the magazine, think they are liberal and free! It is the freedom of a prison-yard," Thoreau wrote in his journal. $5^{8}$ It seemed to him that the fundamental impulse of human choice was to enslave and regulate, not conserve and revere. In the process, people had shackled their very souls. The only viable remedy was for individuals to return to nature, where 
they could profitably remit control over their souls and their senses. Wild Fruits, ideally, would facilitate that reclamation.

\section{A Bible for New England}

Despite his lofty goals, Thoreau was eminently aware of his text's limitations. First among them was geography. His purview was New England; others would have to write nature's bibles for their own particular areas of the world. He made no apologies: his concern was for the soul of New England; Wild Fruits was a bible for New Englanders rooted in the landscape of New England. And on that subject, Thoreau was undeniably an expert. He had surveyed the land, walked it, settled on a pond's edge, and traveled to its seashores and its rocky mountains. There was, he came to believe, no place more beautiful, more divine, and therefore more relevant to its people's spiritual growth than their native soil. "Do not think, then, that the fruits of New England are mean and insignificant while those of some foreign land are noble or memorable. Our own, whatever they may be, are far more important to us than any others can be. They educate us and fit us to live here. Better for us is the wild strawberry than the pine-apple, the wild apple than the orange . . . and not on account of their flavor merely, but the part they play in our education" (p. 5). For years, New Englanders had been importing exotic fruits and delicacies from distant countries, when, Thoreau asserted, they need only have stepped foot outside their doors. The native flora and fauna there, if properly observed, would have transported them to lands nearby yet all too unfamiliar.

Beyond being edible and educative, natural objects were worthy of worship. As I noted earlier, Thoreau differed from Emerson insofar as he believed that nature was not merely a symbolic conduit connecting man and God; rather, it possessed its own distinct integrity. Speaking about pumpkins-a gourd indigenous to the northeastern states-Thoreau exclaimed, "This is a genuine New England scene. The earth blazes not only with sunflowers, but with sun fruits" (p. 148). Such passages reveal Thoreau's evangelistic and prophetic aspirations. On the subject 
of blueberries, his remarks were quite literally sacramental. "Man at length stands in such a relation to Nature as the animals which pluck and eat as they go. The fields and hills are a table constantly spread. Diet drinks, cordials, wines of all kinds and qualities are bottled up in the skins of countless berries for the refreshment of animals, and they quaff them at every turn. They seem offered to us not so much for food as for sociality, inviting us to picnic with Nature. We pluck and eat in remembrance of her. It is a sort of sacrament, a communion-the not forbidden fruits, which no serpent tempts us to eat. Slight and innocent savors which relate us to Nature, make us her guests, and entitle us to her regard and protection" (p. 52). Evident herein is Thoreau's reverence for nature as a physical reality as well as Nature as a creative force. The Creator was inseparable from its creation. By consuming a blueberry (or any edible substance, for that matter) from this natural "table constantly spread," humanity partakes of both nature and Nature-just as a Christian at the communion table partakes of the bread and the wine as well as of Christ's essence.

All the senses, not just sight and taste, must be heightened if the individual were to engage with nature fully and, thereby, experience a religious or transcendent awakening. ${ }^{59}$ Proper listening or hearing, like sight, was another test of spiritual readiness. In his journal, Thoreau noted that "Nature has taken equal care to cushion our ears on this finest sound and to inspire us with the strains of the wood thrush and poet. We may say that each gnat is made to vibrate its wings for man's fruition. In short, we hear but little music in the world which charms us more than this sound produced by the vibration of an insect's wing and in some still and sunny nook in spring." 60 To the saunterer or dawdler well prepared, the sound of a gnat could inspire reverence just as readily as the sight of a lush garden or sparkling stream. Nature, Thoreau discovered during his many forays, captivated every sense, often combined in a veritable chorus of sensory experience. He writes in Wild

\footnotetext{
${ }^{59}$ Hodder, "Ex Oriente Lux," p. 416.

${ }^{60}$ Thoreau, Journal, 12:148.
} 
Fruits of a moment when, while walking in a field, he felt "an expansion of all my being for all the learning in the world." In that moment, he was overwhelmed with what he identified as "Liberation and enlargement-such is the fruit which all culture aims to secure." Suddenly, Thoreau recalled, he "knew more about my books than if I had never ceased studying them. I found myself in a schoolroom where I could not fail to see and hear things worth seeing and hearing, where I could not help getting my lessons, for my lesson came to me" (p. 57). His senses were alert, primed for knowledge and for understanding, and so when revelation came in that field while he strode about looking for huckleberries, he was ready to receive it.

Also notable in this and other passages is Thoreau's habitual proclivity to educate his readers. Sacred texts are, with few exceptions, intended to be instructive. In Wild Fruits, Thoreau hoped to teach not by obtruding his authority in the form of commands and sanctions but by unfolding his own experience and thoughts about nature and the human condition, as in the passage above. Occasionally, however his language betrays the influence of more established sacred texts. In several instances, he speaks directly to his readers as the authoritative prophet. "Thus, any summer," Thoreau writes, "after spending the forenoon in your chamber reading or writing, in the afternoon you walk forth into the fields and woods, and turn aside, if you please, into some rich, withdrawn, and untrodden swamp, and find there bilberries large and fair awaiting you in inexhaustible abundance. This is your real garden" (p. 32). The last line is cast as a reprimand, an imperative. Nature is "your real garden," Thoreau states unequivocally, wherein garden refers to a source of abundant truth and knowledge. As opposed to the artificial "gardens" of the sitting room, library, or church, nature is both the literal and analogical garden. By interjecting his own authoritative voice, along with a number of parable-like stories, Thoreau evokes the primary features of sacred texts. ${ }^{61}$

\footnotetext{
${ }^{61}$ Thoreau filled his journal with what can only be described as parables or morality tales. Such parables occur in a number of chapters in Wild Fruits, for example the "Cultivated Cherry," "High Blueberry," "Black Huckleberry," and "Watermelons"
} 
If readers could recognize in Wild Fruits the textual markers of a biblical prophet, they might be more likely to treat his book as a bible of sorts. As I mentioned earlier, Thoreau believed that the duty of the poet-prophet was to translate nature into a language humanity could understand or, as Sharon Cameron phrases it, to "present his reverence for nature in a way that makes it accessible to others within the circumscriptions of literary conventions." ${ }^{62}$ His adoption of textual paradigms found in well-known sacred texts was one means of doing so and one he certainly felt comfortable so doing, having been steeped in America's culture of sacred texts.

Less familiar, and certainly not so traditionally biblical, were Wild Fruit's taxonomic passages. For Thoreau, such instances of pure description were no less spiritual, but he was also convinced that the language and methods of naturalism, of observation, of science, needed to be recast. Though he appreciated and consistently employed standard scientific procedures in his work, he believed that scientists had taken them too far, at times to the expense of their subjects. "Science is inhuman," wrote Thoreau in his journal. "Things seen with a microscope begin to be insignificant. So described, they are as monstrous as if they should be magnified a thousand diameters. Suppose I should see and describe men and houses and trees and birds as if they were a thousand times larger than they are! With our prying instruments we disturb the balance and harmony of nature." ${ }_{3}$ Furthermore, science tended to conclude its inquiry once the "facts" were discovered. Science lacked the means (or inclination) to animate or invest effort in the search for higher truths. Institutional religion, on the other hand, suffered from its aversion to proper scientific methods of observation and fact finding, relying solely on dogma and tradition to reinforce its truth and to foreclose all others. ${ }^{64}$

\footnotetext{
chapters, to name a few. He rarely mentions interactions with other people in his journal, and when he does, most often he does so with little comment or editorializing.

${ }^{62}$ Cameron, Writing Nature, p. 24.

${ }^{6}$ Thoreau, Journal, 12:170-71.

${ }^{64}$ See Johnson, “Thoreau’s Redemptive Work," p. 28.
} 
In Wild Fruits, Thoreau hoped to fuse the good from both religion and science while dispensing with the bad. In one such case, after describing the home and habitat of the chestnut in extensive detail, he waxed reverential. "Such is the cradle, thus daintily lined, in which they have been rocked in their infancy," he says of the shell. "With what steadiness the nuts must be held within these stout arms - there can be no motion on their bases - and yet how tenderly, by a firm hold that relaxes only as they grow, the walls that confine them, superfluously strong as they seem, expanding as they grow!" (p. 214). Even though he is still simply describing, Thoreau infuses his scientific report with a sense of wonder and awe, a worshipful attitude generally reserved for humanity's approach to the divine.

Through both its meticulous description of its specimen and the blissful demeanor of its beholder, the passage on chestnuts has the effect of beguiling its reader. The necessary first step to any religious experience involving a natural object, Thoreau had explained early on in Wild Fruits, was for the observer to draw a picture of it in his or her "mind's eye" (p. 18). According to Buell, Emerson was the inspiration for Thoreau's model of "image" first, then "idea."65 It is also clear, however, that Thoreau derived this idea as much from Hindu philosophy and Plato as from Emerson himself. What set him apart from those influences was that he went on to immerse himself in scientific methods. Only after he had carefully observed and thoroughly described the detail of a local fruit or flower did his mind settle on the mental image that would offer a glimpse of divinity. His system rests, to borrow Cameron's language, on the distinction between "observation" and "seeing." Observation, in Thoreauvian terms, "anticipates what it hopes to find." Thus, his descriptions were intended simply to set his readers' minds in the proper frame of reference. Seeing, however, uncovers things for which "no expectation can prepare one." Actually seeing, or experiencing "second sight," as noted earlier, was a far more complicated task, one that relied primarily on faith in Nature's ability to reveal the new and unexpected. Thoreau

\footnotetext{
${ }^{6}$ Buell, New England Literary Culture, p. 128.
} 
could not induce second sight in anyone, but he could send readers along the proper path by "[transposing] the visual to a verbal medium," as he did in Wild Fruits. ${ }^{66}$

In this capacity, Thoreau is best characterized as a translator. Though, he made his presence known at various points throughout the text, when his prophetic calling demanded it, he retreated and let nature speak through him. In Wild Fruits he transcribed nature's "revelation" into printable, readable form. Unlike in his earlier writings, he no longer wrestled with himself and his place in nature. Throughout Wild Fruits, he embodied Emerson's "transparent eyeball." Unplagued by self-consciousness and utterly receptive to the divinity around him, he became the conduit for nature's "Word." 67

Of course, like any translator, Thoreau determined what should be included in his text and what omitted. In Ktaadn and Cape Cod, he confronted Nature's malevolence; in Wild Fruits, he avoided the issue entirely. Skirting Nature's wrath, he focuses instead on her mercy, love, and abundance, her maternal nurturing, her health-giving touch. "What though the woods be cut down; it appears that this emergency was long ago anticipated and provided for by Nature, and the interregnum is not allowed to be a barren one. She not only begins instantly to heal that scar, but she compensates us for the loss and refreshes us with fruits such as the forest did not produce. As the sandal wood is said to diffuse a perfume around the woodman who cuts it, so in this case Nature rewards with unexpected fruits the hand that lays her waste" (p. 44). Even as humanity devastates nature, she forgives people their sins and provides them whatever they need to sustain themselves, even to prosper. This is the nature/Nature Thoreau chooses to relate.

\section{Creating a New Generation of Prophets}

Thoreau's benevolent force may not have been the nature others found in their own journeys into the woods. However,

\footnotetext{
${ }^{66}$ Cameron, Writing Nature, p. 14.

${ }^{67}$ Emerson, "Nature," in The Spiritual Emerson, p. 26.
} 
Thoreau did not feel it was his duty-or right-to regulate anyone else's experience and interpretation of nature. The intention of his scriptural project was to return humanity to its essential wildness, discovered in the course of a direct engagement with nature, not to interpret its experience of the natural world. ${ }^{68}$ Perhaps, some would gravitate toward the dangerous in nature. Historically, religion had not hesitated to instill terror and dread to inculcate belief. If the fearsomeness of the ocean enabled some people to experience the divine, so be it. But if he were to persuade people to enter the woods, Thoreau had to present the forest as a hospitable, perhaps even magical, environment. "If you would be a great prophet," writes Bradley Dean in his introduction to Wild Fruits,

history suggests that your first act should be to journey into a remote wilderness, where you must subsist for a goodly time (say forty days and forty nights) on the fruits of the land (locusts and honey, say). While there you must achieve insights into the great mysteries of life, and then you are obliged to return to civilization and teach the import of those mysteries to others. ... But in Wild Fruits [Thoreau's] brand of prophecy manifests itself in a unique manner: by bringing wildness out of the wilderness; or, more properly, by locating wildness within civilization. . . . In these holy places, these natural temples, each of us is able to implement the Transcendentalist's Imperative by learning life's great lessons ourselves, becoming our own prophet, and not having to rely on the mediated testimony of prophets from preceding generations. ${ }^{69}$

Thoreau did not live to complete and publish Wild Fruits. Although his grand plans were left unfinished, his project was not a failure. If his goal was to translate nature into inspired scripture, to fulfill, in other words, the prophet's greatest role,

\footnotetext{
${ }^{68}$ This was not unlike other restorationist movements of the time, for example, the Stone-Campbell movement, whose adherents believed that by reading the biblical books correctly, humanity could return, as literally as was possible without time travel, to the eras in which the books were written. The Stone-Campbellites, like Thoreau, sought to recover something that was lost, though they would most likely have deplored the comparison given Thoreau's desire to uncover the "wild," seemingly savage part of human nature.

${ }^{6}$ Dean, intro. to Wild Fruits, pp. xv-xvi.
} 
then he had done so. Thoreau may not have achieved the status of the biblical prophet, bringing thousands to the faith through the sheer resounding force of his voice, but he was Nature's prophet nonetheless. Translating, in some measure taming, Nature for the masses, he lured them beyond the garden path and into the wilderness, where they too would discover in themselves their essential wildness, their essential relation to divinity.

Lydia Willsky is currently a Visiting Professor of Religious Studies at Whittier College. Her recent research involves the study of alternative scriptures in America and the interpretive practices of nineteenth-century Unitarians. Her first book project involves the Protestant dilemma of religious authority and is due from Lexington Books in 2015. 